ISSN 2078-6441. Вісник Львівського університету. Серія географічна. 2018. Випуск 52. С. 163-169.

Visnyk of the Lviv University. Series Geography. 2018. Issue 52. P. 163-169.

http:/ / dx.doi.org/10.30970/vgg.2018.52.10182

911.3:008

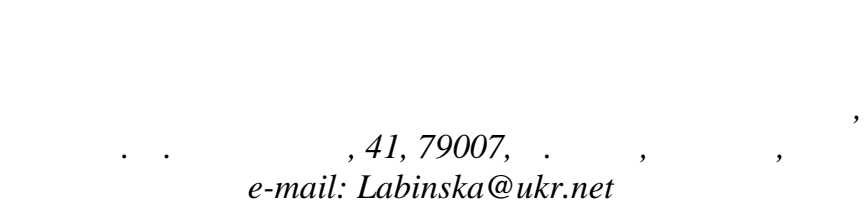

європейській історіогр фії в гомий вплив вихідців 3 онголії н соці льне, культурне т економічне життя н родів вр зії, поневолених ними у ст., позн ч ють л тинським терміном Pax Mongolica (монгольський світ). ст. суттєво змінилося тр ктув ння впливу т т рського етносу - ключового ядр вихідців 3 онголії, н східноєвропейську історію. ослідники тепер конст тують вир зні позитивні впливи т т рської експ нсії з до кінця $\mathrm{V}$ ст. н осію. изк фтів, що стосуються присутності т т р в кр їні, зумовил уст лення зн чних відмінностей між укр їцями і росіян ми. обто, в кр їні т т ри були менш впливовими, ніж у осії; політик г лицьких і волинських князів щодо з войовників у той ч с бул чи не н йоптим льнішою для укр їнських земель і відмінною від політики князів остово- узд льської землі; т кож період т т рського п нув ння в кр їні був зн чно коротшим (до середини $\mathrm{V}$ ст.).

еополітичні “вз ємини” осковії з римським х нством у XV-XVII ст. у контексті його турецької в с льної з лежності, б г то в чому визн чили у м йбутньому долю укр їнських земель. исленні т т рські н біги у XVI-XVII ст. н укр їнські землі супроводжув лися руйнув нням поселень, нищенням місцевого н селення, проте м йже повсюдно збереглися вл сні геогр фічні н зви, які виникли ще до н в ли.

опонімічний сп док доби т т рської експ нсії в кр їні предст влений перев жно комонім ми, гідронім ми, дромонім ми, в гомий пл ст зосереджений серед мікротопонімів, що потребує дет льніших досліджень. еручи до ув ги ргументи істориків, етнологів, етногр фів щодо окремішності т т рського (к з хського) т монгольського етносів, безсумнівно, треб відмовитися від н в'яз ного у ст. у осії “широковжив ного” словосполучення “т т ро-монголи” (як і його н лог - “монголо-т т ри”), не ототожнюючи н зви двох с мостійних етносів. кр їні пр ктично нем геогр фічних н зв, похідних від етнонім “монголи", проте зн чно більше топонімів, утворених від етнонім “т т ри”.

контексті впров джув ної в кр їні політики декомуніз ції треб п м'ят ти про відновлення т т рських н зв у риму, пр ктично тот льно перейменов них у 1944-1945 т 1948 pp.

лючові слов : топонімічний сп док, етноніми, вл сні геогр фічні н зви, т т рський етнос, монгольський етнос.

ояві т т р н терен х кр їни передув л низк н в л: зокрем, після хоз рів н землю иївської усі у ст. вторглись угри; н прикінці - н поч тку ст. з'явилися печеніги; услід з печеніг ми н “землю уську” з йшли узи, бо, як їх ще н зив ли, торки (р зом з берендеями, ковуями, коснич ми, турпіями торки входили до групи чорних клобуків). н ні численними і войовничими половцями, биті рус ми, торки врешті визн ли вл ду київських князів і розселилися вздовж південного порубіжжя ереясл вщини, иївщини, н оділлі, у лицько- олинському князівстві, в окремих міст х. йсильнішою тюркською ордою перед т т рськоюн в лою були половці. ерш зг дк

(C) бінськ ., 2018 
про їхні н п ди н усь н лежить до 1054 р. тнонім половців кипч ки відомий з VIII ст.,

у хідній вропі вони більше відомі під екзонімом кум ни, німці їх н зив ли blaven. воюв вши простори від хідного ибіру і м йже до ун ю, половці д ли їм н зву ум нських ( ешт-і- ипч к), бо оловецьких, степів, які м йже впродовж двох століть були в гомим чинником у житті тодішньої кр їни.

оловці, безперервно з вд ючи усі дошкульних уд рів з півдня, плюндруючи їі поселення, що регулярно відзн ч в літописець, і с мі знесилюв лися. кож їм доводилося одноч сно придушув ти й опір поневолених ними з лишків печенізько-тюркських орд. коли у 1223 р. н рубеж х землі оловецької з'явилися т т ри, ні половці, ні руси, роз'єдн ні у феод льній міжусобиці, не змогли д ти їм декв тного опору.

ійськ ингісх н, рух ючись із ерсії через вК 3, у 30-х рок х ст. ст ли повновл дними господ рями ешт-і- ипч к , з снув ли тут велику й сильну держ ву, відому н сході від н звою лус жучі (дослівно: вотчин жучі, ст ршого син ингісх н . - . .), н з ході - олотої рди (походить від н зви, зг д ної у московських літопис х XVI ст., як п м'ять про золоте ш тро х нської ст вки. - . .).

дро орди сформув ли к з хські роди, які прибули н терени 3 хст ну з території суч сної онголіїн поч тку ст. ік во, що розквіт імперії ингісх н суч сні вчені пов'язують з клім тичними змін ми. доповіді, опубліков ній у Proceedings of the National Akademy of Sciences [3], ідеться про період, який передув в поч ткові пр вління ингісх н й був н дзвич йно посушливий. роте в ч си ктивного розширення імперії, тобто з 1211 по 1225 pp., у онголії уст лився незвично м'який клім т з регулярними оп д ми т помірними темпер тур ми. подібних умов х тр в росл н дзвич йно швидко, з безпечуючи кормом монгольських ск кунів. вич йно, перехід від н дзвич йно посушливої до вологої погоди в той ч с не ст в ні головним, ні єдиним чинником, одн к з вдяки цьому виникли іде льні умови для появи сильного х ризм тичного лідер , який зумів зібр ти численну рмію і зосередити вл ду у своїх рук х. полеон он п рт конст тув в, що з войовницькі війни ингісх н були глибоко продум ними й пров дилися методично пр вильно, і лише тому вд в лися, що відповід ли н явним сил м т 3 соб м. вген рле з свідчив, що військові історики пізніше ргументов но підтверджув ли думку полеон [7, с. 396].

p. лці 16 червня 1223 р. т т ри розгромили об'єдн ні сили русів. роте спр вжня н в л т т рів розпоч л ся у 1239 р., коли було з хоплено ддніпрянщину, оділля, олинь і личину, т кож коли тиєв орд перейшл рп ти. ідомими історичними ф кт ми є поїздк князя нил лицького у 1245 р. до столиці олотої рди з для отрим ння ярлик н упр вління землями, т кож звернення князя до пи имського нокентія IV щодо сприяння у створенні військової протиординської ко ліції р зом з ольщею, ехією, омер нією т ербією, з мість якого він як компенс цію отрим в лише титул короля т корону. прикінці 1254 p. нило лицький перейшов ун ступ проти т т р; були відвойов ні землі вздовж івденного угу, лучі т етерев . дн к у 1256 р. під тиском х нських вимог князь змушений був відд ти н к з про знищення укріплень олодимир, нилов, ремінця, уцьк, ьвов т інших міст. боронні споруди зберегли лише у олмі, який і ст в місцем ост ннього прихистку князя нил .

к сув ння поліконфесійності і прийняття олотою рдою мусульм нств у 1320 р., з пр вління х н збек , спричинило територі льний поділ кр їни н чотири провінціїулуси: рим, р й, орезм, ешт-і- ипч к. XV ст. територі льн диференці ція 
лише посилил ся, ун слідок розп ду олотої рди утворилися стр х нське, 3 нське, 3 хське, римське, ибірське т збецьке х нств, т кож ог йськ рд i осковське князівство. римське х нство здобуло нез лежність у 1443 р., проте вже у 1475 р. місцев феод льн зн ть визн л себе в с лом турецького султ н . еополітичні “в3 ємини" осковії з римським х нством у XV-XVII ст. у контексті його турецької в с льної з лежності б г то в чому визн чили в м йбутньому долю укр їнських земель. гідно з ьвівським літописом, н п ди т т рн землі кр їни відбулися у 1558,1567 , $1575,1588,1590,1594,1618,1619,1620,1621$ т 1633 рр. строзький літопис з фіксув в н п ди т т р і турків н кр їну у 1512, 1516, 1519, 1524, 1527, 1532, 1534, 1550, 1564, $1568,1575,1577,1605,1606,1607,1608,1616$ i 1618 pp. [1, с. 58, 60-61]. . евзо вв ж є, що з кількістю і достовірністю звісток про н п ди т т рі турків н кр їну ьвівський i строзький літописи, як документи, що з'явилися невдовзі після подій, м ють зн чення першорядного джерел . обох літопис х звістки про н п ди з войовників перев жно л конічні. прикл д, перш звістк про н п д т т р н кр їну у 1512 р. сформульов н т к: “ $m$ р пор жено під ииневцем” [1, с. 125]. передодні н весні ерекопський х н енглі ерей вторгся в укр їнські землі, що перебув ли н той ч с під вл дою ольщі, і з з гоном у 25 тис. осіб розмістився між уськом і леськом. відси т т ри розбрелися в усіх н прям х, нещ дно гр був лиміст ісел , з бир лин селення в полон. ольські військ під ком ндув нням . менецького і литовські н чолі 3 . строзьким вд лими діями розгромили т т р під ишневцем (з 1939 р. ишнівець - містечко у ернопільській обл. - . .), де ті зосередили все н гр бов не м йно і полонених. полону звільнили близько 15 тис. осіб, відібр ли н гр бов не добро, супутньо з бр ли близько 10 тис. т т рських коней.

йбільш спустошливі н п ди кримських т т р н оділля i олинь відбулися у 1516 p. свідченнями джерел, зовсім розорено територію н сорок миль уздовж і стільки ж ушир, н д н селенням чинили неймовірні н сильств і гр бунки, з бр но в полон пон д 50 тис. осіб. 3 пит ння польського короля игізмунд до енглі ерея: чому, перебув ючи в мирних відносин х 3 ольщею, він дозволив своїм людям розоряти польські землі, х н відповів, що це зроблено без його відом людьми, яких він не може утрим ти в покорі. с ме з цим н шестям т т р польський хроніст рцін ельський пов'язує поч ток дій укр їнських коз ків. годом кількість коз ків збільшув л ся, походи проти т т р і турків щор зу ч стіш ли.

т ри винищили нем ло місцевого н селення, зруйнув ли б г то сіл і міст. роте м йже повсюдно збереглися вл сні геогр фічні н зви, які виникли ще до н в ли. ч сом з'явилося т кож й топонімічне відобр ження цього історичного періоду.

. триж к [6] з зн ч в, що в кр їні єдиним н йменув нням, з несеним сюди с ме монголо-т т р ми, вв ж ють яр огол у колишньому оменському повіті н олт вщині (тепер умськ обл. - . .). ожливо, ця н зв свідчить про якогось монгол , бо могол, як їх ще н зив ли не тільки в кр їні ( еликі оголи - дин стія феод льних пр вителів у XVI-XIX ст. в ндії; могольськ мов в фг ніст ні - . .).

н чно більше в кр їні вл сних геогр фічних н зв, утворених від слов “т т ри”. ме т к н зив ли конгломер т племен, до якого н леж в с м ингісх н і його внук

тий. о слов, це ім'я т кож відобр жене в укр їнській топоніміці. крім тиєвої гори в иєві (н олом'янці), де, як г д ють, зупинявся тий під ч с облоги иєв , 
тиєвої бр ми (н перехресті вулиць олодимирської і еликої итомирської), тиєвих кург нів (з ибеддю, поблизу сильківської дороги), зг дують т кож тиєву гору в рп т х т ін. дехівському р-ні ьвівської обл. є сел, н зв ні тиїв т рдів.

$\mathrm{XV}$ ст. т рією, бо т рською стороною, н зив в усе лівобережне дніпров'я м ндрівник мвросій онт ріні, який здійснив перепр ву через ніпро у 1474 р. біля м. ерк си. т рськими н зив ли не тільки перепр ви через ніпро, орсклу, сел, улу, інець т інші укр їнські річки, й шляхи, що т м проходили.

о переліку топонімів дослідники дод ють т рське поле поблизу игирин ,

т рську гірку в р йоні ернігов ; н зву поселення т р- рель н місці м. огопіль (теперішній ервом йськ у икол ївській обл.). собливо б г то пов'яз но з цим коренем колишніх ойконімів: $\quad$ рський, $m$ рчин, $л \quad m p щ и н, ~ m p и н$, $m p \kappa$ н олт вщині, $m$ риськ н мельниччині, $m$ ринк н інниччині, $m$ ринівк н итомирщині, $m p \kappa$ н уковині. береглися до сьогодні комоніми $\boldsymbol{m}$ ринів у ьвівській обл., $\boldsymbol{m} \boldsymbol{p} \boldsymbol{\mu} \boldsymbol{н} \boldsymbol{i}-\mathrm{y}$ ернопільській обл., широко відоме село $\boldsymbol{m} \boldsymbol{p} \boldsymbol{i \boldsymbol { \varepsilon }}$ - осередок рекре ції й туризму в в но- $\mathrm{p}$ нківській обл. цим же компонентом нерідко можн зн йти і н зви ч стин поселень, н прикл д, $\boldsymbol{m}$ рський $\boldsymbol{y} \boldsymbol{m}$ у с. т нівці олішні ернівецької обл. $\boldsymbol{m}$ рським н зив ють розт шов ний н південній окр їні м. еремишль ( ольщ ) п горб, який упродовж століть слугув в в жливим пунктом спостереження в оборонній системі кр ю. легендою, п горб висотою пон д 350 м н д рівнем моря н сип ли т т ри н місці похов ння 3 гиблого в бою х н .

т рське передмістя зн не у ьвові. ині одну з вулиць ьвов теж н зив ють

т рською.

дн к чи не н йбільше $з$ нотов но т ких н зв серед гідронімів, особливо н івобережжі. окрем , . триж к зг дує струмок $m$ рин у с. м ліївк олт вської обл., потік з т кою ж н звою у с. енесл вівк поблизу р. сел. $m p \kappa м и$ н зив ють притоки истриці у ередк рп тті, м ри н ніпропетровщині, ереднього і ижнього ніпр , ижнього ог чик н ерсонщині, уч ви у хідних рп т хт б г то інших.

$\boldsymbol{m}$ рським зветься одне з озер непод лік с. р нівк н олт вщині, $\boldsymbol{m}$ ровим болото н ернігівщині. Г то т ких н зв, природно, є й у риму, н прикл д, урочищ

$\boldsymbol{m}$ ркой і $\boldsymbol{m} \boldsymbol{p}$ - $\boldsymbol{c}$ м нкой. им ло в кр їні $є$ т рських могил. дн 3 них м $є$ ж двін зви - $\boldsymbol{m}$ рськ і урецьк (ус. елик епетих ерсонської обл.).

ро турків н Г дує урецький в $\boldsymbol{л}$ (12-15-метровий рів), який простяг ється від поріжжя до гирл ніпр вздовж його лівого берег, викоп ний ще у XV ст. 3 ч сів турецького пр вління для з хисту від н п ду з м терик . Г дув нням про турків слугують т кож урещький міст у м'янці- одільському, урецьк гірк в лешк х, урецький потік - н в но- р нківщині, урецьке кл довище біля с. риморське порізької обл. чевидці зг дують т кож про місцевість урок під м нню. межі між ерсонською обл. т нексов ним римським півостровом з 2014 p. діє “ урецький в $л$ ”.

тлі доволі зн чного топонімічного сп дку т т рської доби в кр їні н суч сному ет пі вчені кцентують ув гу н непр вомірності термін т т ро-монголи, як і його н лог монголо-т т ри. к доводять історики, етнологи, етногр фи, т т рський (к з хський) т монгольський етноси у минулому не м ли нічого спільного, до того ж, у -

ст. існув ли лише окремі племен (хорчини, дж рути, оннюти, хешигтени, х р чини т ін.), які вже у процесі под льшого розвитку сформув ли монгольський н род. 
вні історики л но рпіні, ільгельм де убрук, шид- д- ін, жувейні т інші, пр ці яких слугув ли н дійним джерелом інформ ції про події ст., ніколи не вжив ли словосполучення т т ро-монголи. свідчують, що икол $р$ мзін у пр ці “ стория госуд рств оссийского” (1803-1826), доволі вторитетній у осії, цей термін т кож не використовув в [2]. ловосполучення т т ро-монголи з пропонов не . умовим у 1823 р., с ме в ч си “в гомого коригув ння” російської історії, з поч тков ного ще териною . н к зом згори цей термін т к ктивно проп гув ли впродовж н ступних ст років, що він уст лився і в осії, і в вропі.

. ілінський ув ж є це словосполучення штучним витвором російської н уки, що “використ ний для приниження тюркських племен, будівничих олотої рди” [2, с. 93].

т ри 3 мовою, побутом, культурою т всім зовнішніми озн к ми є цілковито тюркським етносом, монголи - с мостійним, нез лежним від тюркської спільноти етносом, який н лежить до монголоїдної р си і впродовж тисячоліття зберіг є свою неповторну с мобутність, н ціон льні звич ї, культуру й мову, що підтверджують прискіпливі дослідження десятк монгольських племен.

прикл д, згідно з опис ми тих же л но рпіні т ільгельм де убрук, у монголів менші кочові орбіти, ніж у киргизів (к з хських родів ч сів олотої рди); з звич й, монголи переміщув лися не більше, ніж н десять верств, тоді як х н тий з військом н конях кочув в від р. м до берегів спійського моря. ля перевезення свого помешк ння і ск рбу монголи використовув ли верблюдів, рідше - биків, з пряжених в одноколки, не м ючи н той ч с юрт н колес х. фіксов н т кож помітн відмінність одягу т головних уборів монгольських і к з хських жінок у д вні ч си. ік во, що подібні до д вніх головних уборів к з шки носять і сьогодні, серед монгольських жінок т кої історичної сп дковості не виявлено. ідмінності між монгол ми й т т р ми простежено й у спожив нні їжі т н поїв: н прикл д, монголи ніколи не пили води, лише ч й 3 молоком і деколи з м слом, випив ючи до 20 горнят 3 день; для бідняків т кий ч й 3 дод в нням до нього пересм женого прос був єдиним х рчем. 3 хище з сів олотої рди п'ють кумис і м'ясну шурпу. уттєво відмінними є т кож риту ли похов ння в к 3 хів т монголів.

и не н йужив ніших у т т р слів “х н” i “курулт й” у монгольській мові нем .

1246 р. чотири тюркські роди киятів, меркитів, н йм нів і киреїтів н курулт ї обр ли

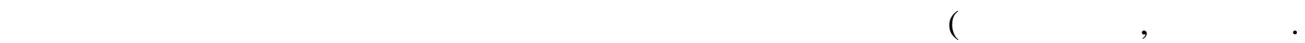
шин- - н йвищ гор , -гис- - промінь і тюрк. $\boldsymbol{x} \boldsymbol{\boldsymbol { \mu }}$ - вл ститель, мон рх), що озн ч ло високий, світлосяйний х н. ільки н курулт ї, звич євому риту лі тюркських н родів, який досі зберігся в к з хів, можн обр ти х н , згідно зі звич єм, піднім ючи його н білій повстині н д голов ми людей.

ідомо, що ингісх н вів щоденники, пис в ук зи т листи, користув вся в побуті рідною йому уйгурською мовою, пис рі т керівники х нських к нцелярій, якими були перев жно кит йці, змушені були вжив ти рідну (тюркську) мову х н . сі х нські діти м ли імен к з хського походження: ту, ерке, еркеч p, рд, ейб н, ув л, нгкум, ингкур; усі діячі імперії ингісх н т кож м ли к 3 хські імен .

тже, у першій половині ст. н терени вропи х н тий вивів стовідсотково тюркомовне н селення, 3 якого згодом сформув вся к 3 хський етнос. хоч в л н-

торі вст новлено величний п м'ятник ингісх ну (як і в екіні), серед суч сного монгольського етносу, який мешк є н терен х онголії т ит ю, нем є племен, із яких 
походить рід ингісх н , його дружин , родичі, діти - киятів, киреїтів, н йм нів т меркитів. лишки цих родів, які мешк ють н території суч сного ит ю, пов'язують себе з к 3 х ми, не з монгол ми, до того ж, мову і культуру сповідують к 3 хську. ивно, шо н тлі кит йсько-монгольської суперечки стосовно походження ингісх н т сп дку величі збудов ної ним держ ви мовчить 3 хст н, м ючи неспростовні ргументи.

меж х укр їнських земель м йже повсюдно збереглися вл сні геогр фічні н зви, які виникли ще до н в ли т т рів у X -XVI ст. опонімічний сп док доби т т рської експ нсії в кр їні предст влений перев жно комонім ми, гідронім ми, дромонім ми, в гомий пл ст зосереджений серед мікротопонімів, що потребує дет льніших досліджень. огляду н ргументи вчених, безсумнівно, треб відмовитися від н в'яз ного “широковжив ного" словосполучення т т ро-монголи (як і його н лог - монголот т ри), не ототожнюючи н зви двох с мостійних етносів.

контексті впров джув ної в кр їні політики декомуніз ції потрібно п м'ят ти про відновлення т т рських н зв у риму, пр ктично тот льно перейменов них у 1944-1945 т 1948 pр., до того вибірково змінених н догоду ц рському режиму після з воюв ння півостров у 1783 р.

1. евзо . . ьвівський літопис і строзький літописець. иїв : ук. думк , 1970. $200 \mathrm{c}$.

2. ілінський . оскв рдинськ ( $\quad$ XVI століття): сторичне дослідження. иїв : - - - - - - ,2015. - 656 c.

3. ук чёные: $з$ воев ниям ингисх н способствов ло потепление [ лектронный pecypc]. ежим доступ : http:/viknaodessa.od.ua/news/? news=90518.

4. ркер ж. тл с “сторія світу” / [пер. 3 нгл. . ив к, . одзінськ ]. иїв : “ ртогр фія”, 2008. 192 с.

5. лохій . р м вропи / пер. 3 нгл. . лочк . рків : нижковий луб “ луб сімейного дозвілля", 2016. . 82-96.

6. триж $\kappa$. . ро що розповід ють геогр фічні н зви ( ліди н родів н к рті ). иїв : ук. думк , 1967. 127 с.

7. рле. полеон. оскв : ; стрель; иев: .2011. . 396.

\section{REFERENCES}

1. Bevzo, O. (1970). Lvivskyi litopys i Ostroz'kyi litopysec'. Kyiv: Naukova dumka, 200 pp. (in Ukrainian).

2. Bilinskyi, V. (2015). Moskwa Ordynska ( -XVI stolittia): Istorychne doslidzhennia. Kyiv: A-BA-BA-HA-LA-MA-HA, 656 pp. (in Ukrainian).

3. Nauka Uchonyie: zawoiewaniiam Chynhischana sposobstwowalo potepleniie. Retrieved from http:/viknaodessa.od.ua/news/?news=90518 (in Russian).

4. Parker, J. (2008). Atlas “Istoriia svitu” (N. Sywak \& O. Chodzinska, Trans.). Kyiv: DNVO "Kartografiia”, 192 pp. (in Ukrainian).

5. Plokhii, S. (2016). Brama Evropy (R. Klochko, Trans.). Kharkiv: Knyzkowyi Klub "Klub simeinoho dozvillia", 82-96 (in Ukrainian). 
6. Stryzhak, O. (1967). Pro scho rozpowidaiut' geohrafichni nazwy (Slidy narodiw na karti URSR). Kyiv: Naukova dumka, 127 pp. (in Ukrainian).

7. Tarle, Y. (2011). Napoleon. Moskva: AST; Astrel'; Kyiv: TOV CNML, 396 pp. (in Russian).

m ття: н дійшл до ред кцї̈ 15.12.2017

доопр иьов н 12.01.2018

прийнят до друку 06.02.2018

\title{
THE TOPONYMIC LEGACY OF THE TATAR EXPANSION PERIOD IN UKRAINE
}

\author{
alyna Labinska \\ Ivan Franko National University of Lviv, \\ P. Doroshenko St., 41, UA - 79007 Lviv, Ukraine, \\ e-mail: Labinska@ukr.net
}

In European historiography, the influential influence of immigrants from Mongolia on the social, cultural and economic life of the Eurasian people, enslaved by them in the 13th century, is marked by the Latin term Pax Mongolica (Mongolian World). In the twenty-first century, the interpretation of the influence of the Tatar ethnos - the key nucleus of immigrants from Mongolia, on Eastern European history - has changed significantly. The researchers now state the expressive positive effects of Tatar expansion from the XIII to the end of the fifteenth century to Russia. A number of facts concerning the presence of the Tatars in Ukraine led to the establishment of significant differences between Ukrainians and Russians. In Ukraine, the Tatars were less influential than in Russia. The policy of Galician and Volyn princes about the invaders at that time was perhaps the most optimal for the Ukrainian lands and different from the policies of the princes of the Rostov-Suzdal land. In addition, the period of Tatar rule in Ukraine was much shorter (by the middle of the XIV century.).

The geopolitical "relations" of Muscovy with the Crimean Khanate in the 15th-17th centuries, in the context of its Turkish vassal dependence, largely determined the fate of the Ukrainian lands in the future. Numerous Tatar raids in the XVI-XVII centuries the Ukrainian lands were accompanied by the destruction of settlements, the destruction of the local population, but almost everywhere preserved their own geographical names that arose before the invasion.

The toponymic legacy of the Tatar expansion in Ukraine is represented predominantly by comonomies, hydronyms, dromonyms, and a heavy reservoir is concentrated among microtoponomisms, which requires more detailed research. Taking into account the arguments of historians, ethnologists, ethnographers, with regard to the separation of the Tatar (Kazakh) and Mongolian ethnic groups, it is undoubtedly necessary to abandon the imposed in the nineteenth century, in Russia, the "widely-used" phrase "Tatar-Mongols" (as well as its analogue - "Mongol-Tatars"), not identifying the names of two independent ethnic groups. In Ukraine, there are virtually no geographical names derived from the ethnonym "Mongols", but much more toponyms, formed from ethnonym "Tatars".

In the context of the policy of de-communization introduced in Ukraine, one should remember the restoration of Tatar names in the Crimea, which were practically totally renamed from 1944-1945 and 1948.

Key words: toponymic heritage, ethnonyms, own geographical names, Tatar ethnos, Mongolian ethnos. 